\title{
Lose one's life and lose one's job with singular they: two constructions, two regional varieties, many practical aspects of working with mega-corpora
}

\author{
Lose one's life [stracić życie] i lose one’s job [stracić pracę]
} z zaimkiem they odnoszącym się do liczby pojedynczej: dwie konstrukcje, dwa warianty regionalne języka angielskiego, wiele praktycznych aspektów pracy z dużymi korpusami tekstów

\author{
Karolina RUDNICKA ${ }^{1}$ \\ University of Gdańsk
}

\begin{abstract}
The paper compares the usage of singular they with two morphologically similar constructions in British and American English. The constructions in question are lose one's life and lose one's job. The results obtained suggest that singular they, at least used with the two constructions in focus of this work, seems to be more widely used in the American variety of English than in the British variety. An additional aim of this work is to present and discuss some practical aspects of working with mega-corpora. The work shows how and where quantitative language studies need to be accompanied by manual and qualitative investigations. The corpora used in this work are the British National Corpus (BNC) and the Corpus of Contemporary American English (COCA).

Keywords: Singular they, corpus linguistics, mega-corpora, construction grammar, British English, American English, pronoun
\end{abstract}

(D) https://orcid.org/0000-0001-8097-6086

University of Gdańsk, Faculty of Languages

karolina.rudnicka@ug.edu.pl 


\section{Streszczenie}

Artykuł porównuje użycie zaimka they w odniesieniu do podmiotów w liczbie pojedynczej z dwiema, z punktu widzenia morfologicznego podobnymi do siebie, konstrukcjami w wariancie brytyjskim i amerykańskim języka angielskiego. Badane konstrukcje to lose one's life [stracić życie] i lose one's job [stracić pracę]. Uzyskane wyniki sugerują, że they odnoszące się do liczby pojedynczej jest bardziej rozpowszechnione w amerykańskim wariancie języka angielskiego niż w brytyjskim. Dodatkowym celem artykułu jest zaprezentowanie i przedyskutowanie praktycznych aspektów pracy z dużymi korpusami językowymi. Praca wskazuje w których miejscach badania ilościowe muszą iść w parze z badaniami jakościowymi. Korpusy zastosowane do wykonania badania to Brytyjski Korpus Narodowy (BNC) i Amerykański Korpus Współczesnego Języka Angielskiego (COCA).

Słowa kluczowe: They odnoszące się do liczby pojedynczej, językoznawstwo korpusowe, korpusy językowe, gramatyka konstrukcyjna, brytyjski angielski, amerykański angielski, zaimek

\section{Introduction: construction grammar, singular they and mega-corpora}

This work subscribes to construction grammar, and the phrases which are being looked at are termed as constructions. According to Hilpert (2014: 22), constructions are "linguistic generalizations that speakers internalize". Linguistic approaches which see morphemes, words, idioms and abstract phrasal patterns as constructions, do not accept a clear-cut division between the syntax and the lexicon, but assume that all constructions belong to a lexicon-syntax continuum - the so-called construction (Hoffmann \& Trousdale 2013: 1). The two constructions studied here are lose one's life and lose one's job. They, without doubt, are morphologically similar - both have a verb + possessive pronoun + object order, the verb is in both cases the same one, to lose. Also, the situations to which the constructions refer, bear similarities, namely the possessor of an object (the doer) is deprived of the object, the object being in one case - the life of the subject, and, in another case, the job of the subject.

An interesting aspect is the fact that, according to Cambridge Dictionary Online, lose one's life is an idiomatic construction. There is a separate entry devoted to the phrase ${ }^{2}$, however, no such entry is devoted to the construction lose one's job. Still, if one consults other online dictionaries, there are some that also list the latter construction as an idiom, for instance Merriam-

2 Cambridge Online Dictionary, s.v. lose your life, retrieved on May 17, 2020 from https://ictionary.cambridge.org/dictionary/english/lose-your-life. 
Webster ${ }^{3}$. The question as for whether one expression is more idiomatic than the other, remains open and, very likely, depends on the context of the concrete utterance. Sentences (1) and (2) exemplify the use of the two constructions.

(1) His mother Princess Diana lost her life chased by paparazzi. (COCA; 2019)

(2) I'm sorry that all these folks may lose their jobs, very sorry. (COCA; 2012)

Another construction in focus of this work is the singular they, in particular singular their, resulting from the use of gender-neutral they. Singular they is a much-discussed (e.g. Gernsbacher 1997; Baron 2018 \& 2020; Solomon 2019; Bradley 2020, McCarthy 2020) personal pronoun, which has a long history of usage in the English-speaking world. According to Baron (2018), the singular usage of they can be traced back to the fourteenth century and it "has become the pronoun of choice to replace he and she in cases where the gender of the antecedent - the word the pronoun refers to - is unknown, irrelevant, or nonbinary, or where gender needs to be concealed". Along similar lines, Solomon (2019: 69) writes:

Singular they has been attested in literature and in common speech for centuries, and continues to be used in spite of nineteenth-century pushback by prescriptive grammarians, because singular they fills the lexical gap in English where an epicene (grammatically unisex) thirdperson singular pronoun should be.

McCarthy (McCarthy 2020: 78) also acknowledges the fact that singular they has already become part of the pronoun system and claims that its advent made the system of she (female) and he (male or generic ${ }^{4}$ ) "defunct".

Baron goes one step further and shows that the pronoun-question seems to be one of the most important questions nowadays, its importance reaching far beyond correctness (2020: 1): " "What's your pronoun?" is an invitation to declare, to honor, or to reject, not just a pronoun, but a gender identity. |And it's a question about a part of speech.". Finally, it is worth mentioning that singular they has recently become Merriam-Webster's Word of the Year $2019^{5}$.

\footnotetext{
${ }^{3}$ Merriam-Webster, s.v. lose one's job, retrieved on May 20, 2020 from https://www.merriamwebster.com/dictionary/lose $\% 20$ one $\% 27 \mathrm{~s} \% 20$ job.

${ }^{4}$ Before 1970s he used to be used as a generic pronoun to refer to both men and women, however a feminist call in the 70s led to its decline (Baron 2020).

${ }^{5}$ Merriam-Webster's Word of the Year 2019: they. Accessed at July, 27, 2020. Available at https://www.merriam-webster.com/words-at-play/word-of-the-year/they.
} 
The present work aims at contributing to the research on singular they, and the possessive pronoun their used with regard to singular subjects, exemplified in (3), by looking at whether and how it is used with the two constructions of choice.

(3) I suppose it's just that everyone has their own little routines for doing things. (BNC; 1991)

The main goal of the paper is to present an account of the differences between the two varieties of English studied, the British and American English, with regard to the usage and structure of the two studied phrases and, in this context, with a special focus on the usage of singular they. The methodology presented in the next part, provides a valuable addition to the work on its own, as it could be seen as an example of working with mega-corpora and big amounts of linguistic data and the potential problems one may come across.

This paper is structured as follows: the next (second) section contains a detailed description of methodology and the pitfalls of working with large amounts of data; the third section presents the results and describes the tendencies that we see by comparing the different datasets; the fourth part discusses the potential explanations between the datasets.

\section{Methodology}

The corpora used for this study are i) the British National Corpus (BNC)6; and; ii) the Corpus of Contemporary American English (COCA $)^{7}$. Whereas COCA, with its (more than) one billion words of text is often given as an example of a mega-corpus, some doubts may arise as to whether we can refer to the BNC as to a mega-corpus. Weisser (2016: 30) suggests a threshold of 100 million words of text and according to his classification (2016: 20, Table 2.6) both COCA and the BNC can be termed as modern mega corpora.

The present section contains particular steps, which are taken in order to obtain the picture of how frequent the studied phrases are, which variants happen to be the most popular ones and if there are any differences with regard to the use of singular and plural they between the two regional varieties.

\footnotetext{
6 The BNC contains approximately 100 million words of text texts from different genres (e.g. fiction, newspapers, magazines, spoken and academic) and is available online at https://www.english-corpora.org/bnc/.

7 COCA contains more than one billion words of text from different genres (e.g. fiction, popular magazines, spoken, newspapers, academic texts) and is available online at https://www.englishcorpora.org/coca/.
} 
1) For both the BNC and COCA, the search engine at https://www.englishcorpora.org is used.

2) For lose one's life, two queries are conducted, namely i) [lose] _app* life and ii) [lose] _app* lives. The [lose] part encompasses all inflected forms of the verb to lose and _app* refers to all possessive pronouns.

3) For lose one's job, one query is conducted, namely 1) [lose] _app* [job]. The query is in principle the same as with lose one's life, but since the plural of $j o b$ is regular, one could use the square brackets to see both the singular and plural contexts (with life and lives the use of square brackets does not seem to work as smoothly, so, in order to stay on the safe side, two queries are conducted to account for all of the instances).

4) Two datasets are created - one for the BNC and one for COCA - both of them contain information on all the detected instances of the two types. For the BNC the dataset contains 632 observations, for COCA the number is sixteen times higher -10144 .

5) In the course of data collection, manual qualitative assessment of the data is conducted for results containing the possessive pronoun their, such as lost their life or losing their jobs. The goal is to differentiate between the cases in which their was used to refer to third person singular - with pronouns such as anybody, somebody, everybody, and the cases in which there was a singular object for a plural subject.

6) A careful visual exploration of the data is conducted, as a result of which certain phrases, which, at first sight, may seem to instantiate the constructions in focus, but turn out to be "false positives", can be detected. One such example is provided by cases containing the noun phrase life savings and not just life (37 of them found in COCA; 5 found in the BNC), such as lost their life savings or lost her life savings. These cases are removed from the datasets.

7) The programme of choice for the data exploration and analysis is $R^{8}$, with its integrated development environment RStudio; the graphics are created with the use of the ggplot $2^{10}$ package. Thanks to the careful visual exploration and qualitative assessment of the datasets (described

\footnotetext{
${ }^{8}$ R Core Team (2013). R: A language and environment for statistical computing. R Foundation for Statistical Computing, Vienna, Austria. URL http://www.R-project.org/.

${ }^{9}$ RStudio Team. (2020). RStudio: Integrated Development for R. RStudio, PBC, Boston, MA URL http://www.rstudio.com/.

${ }_{10}$ Wickham, H. (2016). ggplot2: Elegant Graphics for Data Analysis. Springer-Verlag New York. ISBN 978-3-319-24277-4, URL https://ggplot2.tidyverse.org.
} 
in Steps 6 and 7 above), it is hoped that the detection precision is very high.

\section{Results}

In the BNC dataset there 156 instances representing the type lose one's life. They can furtherly be divided among sixteen variants of the to lose one's life construction. Figure 1 presents them all with regard to the number of instances, which were detected.

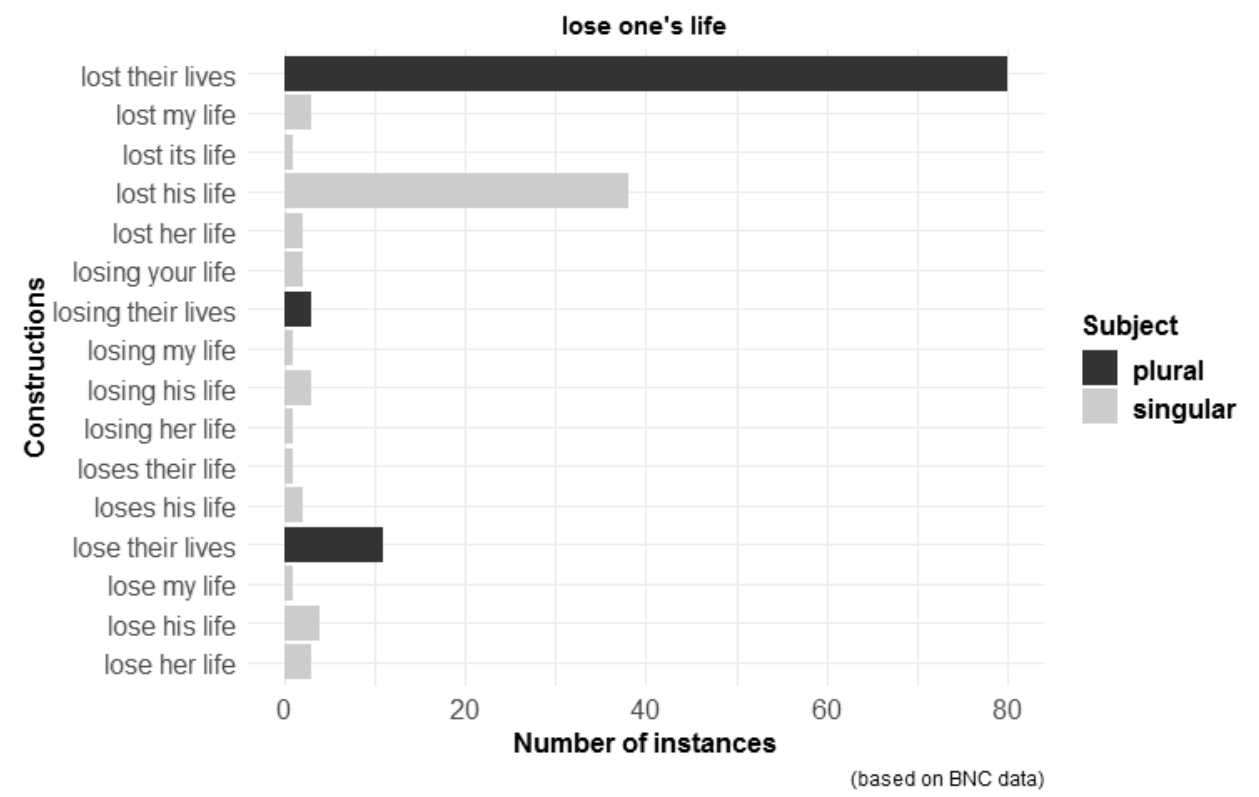

Fig. 1: Sixteen variants of the lose one's life construction extracted from the BNC

As we can see, the most frequent variant is lost their lives - there are eighty instances found in the corpus. It is followed by lost his life, of which there are 38 instances. The third place is taken by lose their lives, with 11 instances. The colour of the bars in Fig. 1 refers to the number of the subject in a given variant.

The second construction in our focus, namely lose one's job, is roughly three times more frequent than lose one's life. There are 476 instances of the construction and twenty-eight different variants. Figure 2 illustrates the frequency of particular variants. 


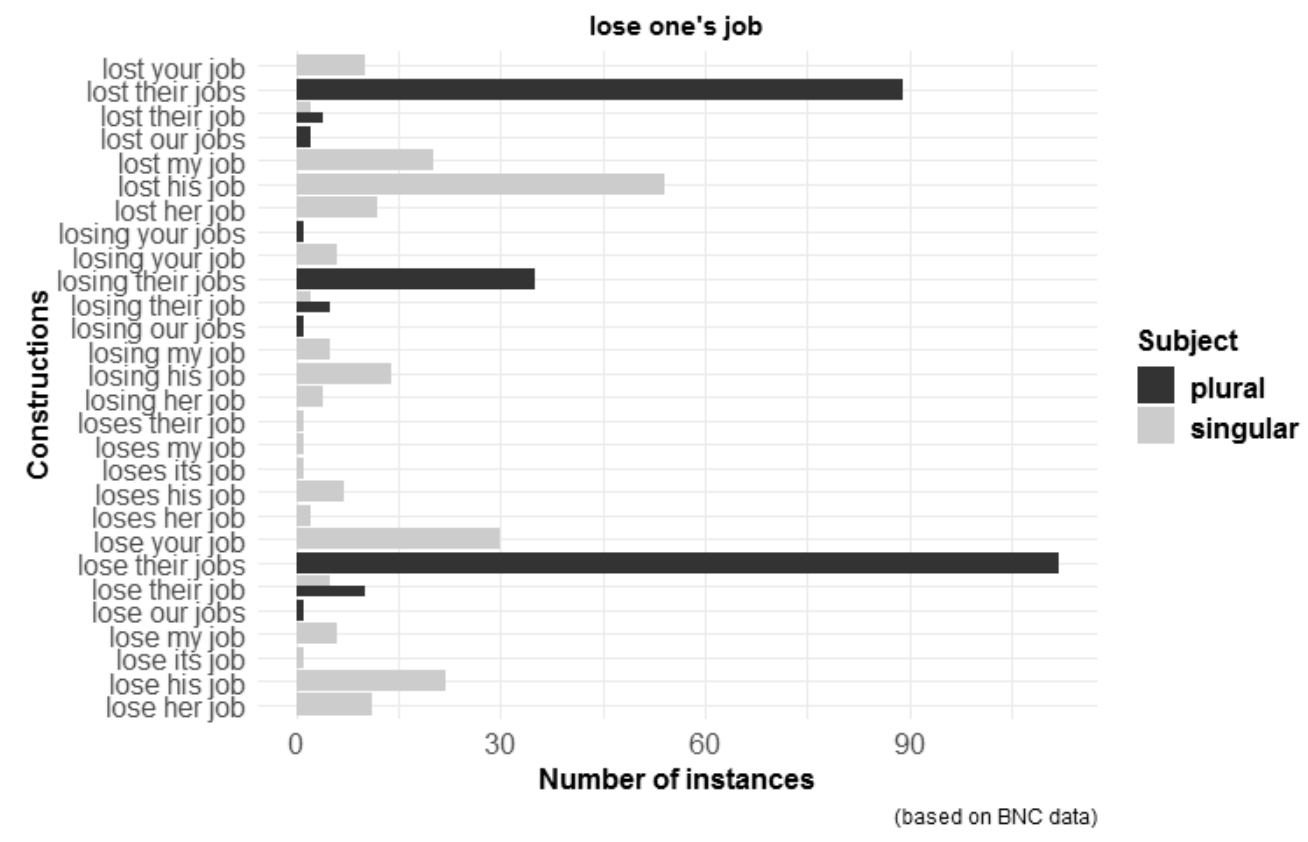

Fig. 2: Twenty-eight variants of the lose one's job construction extracted from the BNC

The most frequent one is lose their jobs, with 112 instances, the second most frequent variant is lost their jobs with 89 instances. The third most frequent is lost his job - there are 54 instances of it.

As has already been stated in the Methodology, all the variants containing their, have been assessed manually so as to qualify them as either instances of singular or plural subjects.

For lose one's life, only 1 instantiation of singular their has been detected, which is exemplified by (4). For lose one's job, the ten cases of singular they discovered belong to the following variants: lose their job (5 instances), losing their job (2 instances), loses their job (1 instance) and lost their job (2 instances) they can be seen below - see (5) and (6). All cases containing a singular they found in the BNC feature a singular object.

(4) And it's the attitude I think that very often causes everything from a major accident like that where someone loses their life (...). (BNC; 1993)

(5) If you can imagine someone losing their job, the depression that actually causes, perhaps both within them (...). (BNC; 1985-1994)

(6) No one dared refuse for fear of losing their job. (BNC; 1995) 
In COCA, there are 2326 instances of lose one's life construction. These cases are divided between thirty-one variants, the most popular of them being lost their lives (1109), lost his life (297), lose their lives (164), losing their lives (101) and lost her life (96). Figure 3 presents a graphical representation of these results.

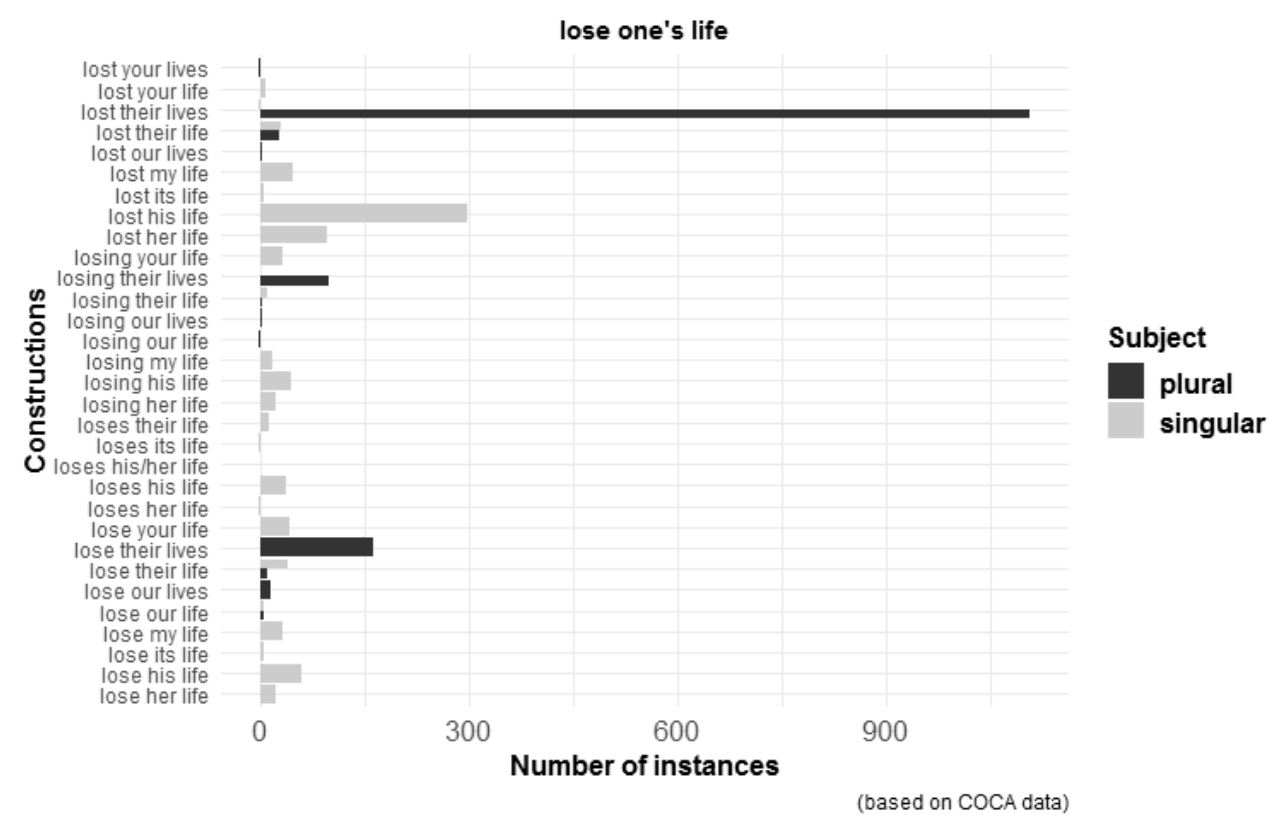

Fig. 3: Thirty-one variants of the lose one's life construction extracted from COCA

Interestingly, in spite of the difference in the sheer amount of data available in COCA (COCA containing almost fifteen times more instances of lose one's life construction than the $\mathrm{BNC}$ ) as compared to the $\mathrm{BNC}$, the three most frequent constructions are the same for both the former and the latter corpus. The situation is almost identical for the lose one's job construction - the three most frequent constructions are the same for both of the corpora, however, the frequency order differs slightly. The most popular variant for this type in COCA is lost his job (1141 instances), the second most frequent is lost their jobs (1085), and the third most frequent, lose their jobs (1064). Figure 4 illustrates the results. 


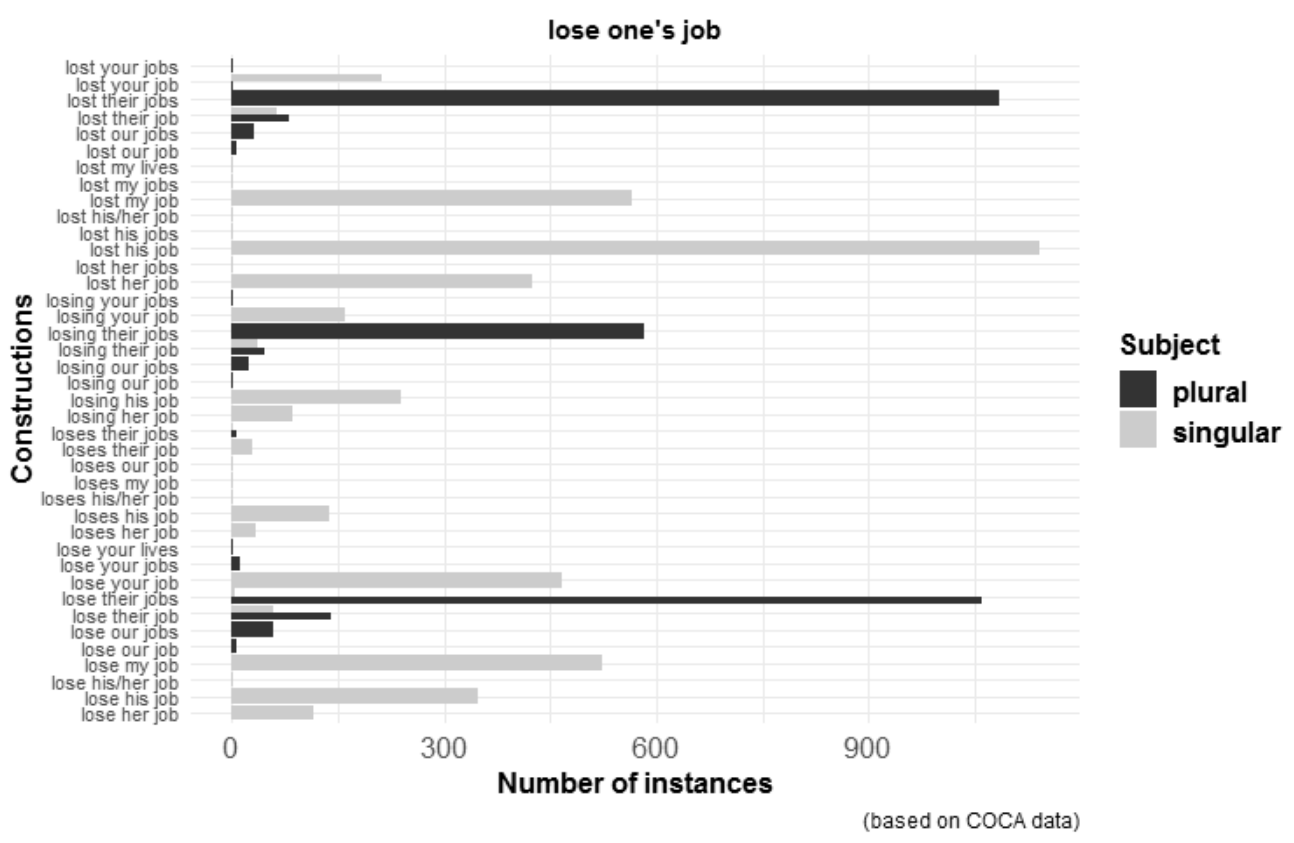

Fig. 4: Thirty-nine variants of the lose one's job construction extracted from COCA

As was the case for the BNC data, a manual exploration of the instances of variants containing their is conducted. During this analysis, sentences containing the particular possessive pronoun are, one by one, read and qualified as being cases of plural or singular subjects.

For the lose one's life type, there are ninety-five instances of singular use of they in the dataset of cases with a singular object; they belong to the variants lost their life (58 instances), lose their life (50 instances), losing their life (13 instances), loses their life (14 instances). Two cases of a singular subject and a plural object have been detected (variant lost their lives). In the case of lose one's job, the whole dataset contains 189 instances of singular they, belonging to the variants lost their job (64 instances), loses their job (29 instances), losing their job (37 instances), lose their job (59 instances). There are six instances of singular they with a plural object - variants lose their jobs (4 instances) and loses their jobs (2 instances).

Table 1 sums up the results obtained for each of the variants in the two corpora; Figures 5 and 6 provide illustrations. The cases with singular subjects and plural objects turned out to be very scarce, which is, however, not surprising, given the fact that in English there is a strong tendency towards distributive correlation (Quirk et al. 1985: 768) - plural subjects typically having plural objects. 
Table 1: Sum-up of the results obtained from the BNC and COCA

\begin{tabular}{|c|c|c|c|c|}
\hline \multirow{2}{*}{ Variants } & \multicolumn{2}{|c|}{ BNC } & \multicolumn{2}{c|}{ COCA } \\
\cline { 2 - 5 } & singular they & plural they & singular they & plural they \\
\hline lost their life & 0 & 0 & 31 & 27 \\
\hline lose their life & 0 & 0 & 40 & 10 \\
\hline losing their life & 0 & 0 & 10 & 3 \\
\hline loses their life & 1 & 0 & 14 & 0 \\
\hline Total for life & 1 & 0 & 95 & 40 \\
\hline lose their job & 5 & 10 & 59 & 141 \\
\hline losing their job & 2 & 5 & 37 & 46 \\
\hline loses their job & 1 & 0 & 29 & 0 \\
\hline lost their job & 2 & 4 & 64 & 81 \\
\hline Total for job & 10 & 19 & 189 & 268 \\
\hline $\begin{array}{c}\text { Total for lose one's } \\
\text { life \& lose one's job }\end{array}$ & 11 & 19 & 284 & 308 \\
\hline
\end{tabular}

lose one's job vs. lose one's life

lost their life, lose their life, losing their life, loses their life

lost their job, loses their job, losing their job, lose their job

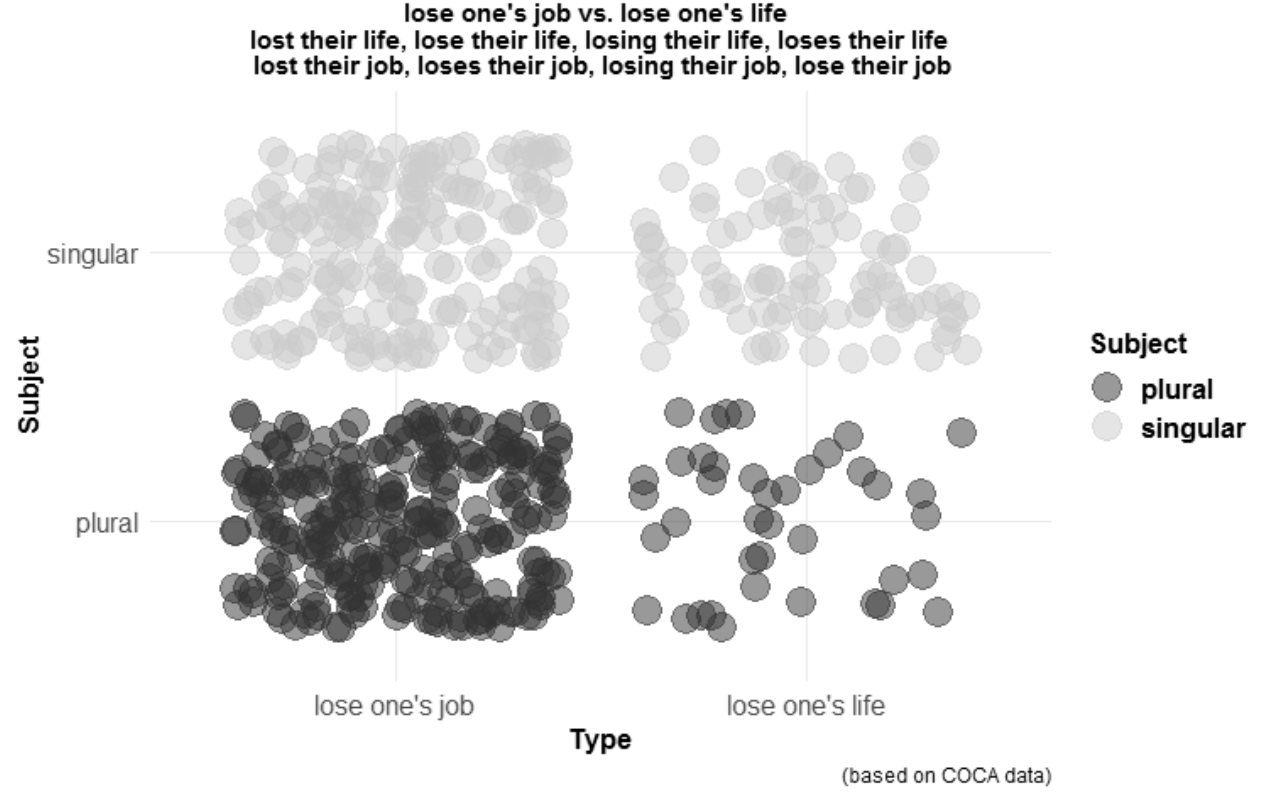

Fig. 5: Cases of singular they for the both types - lose one's life (right) and lose one's job

(left); the particular variants are listed in the plot title. Based on COCA data 


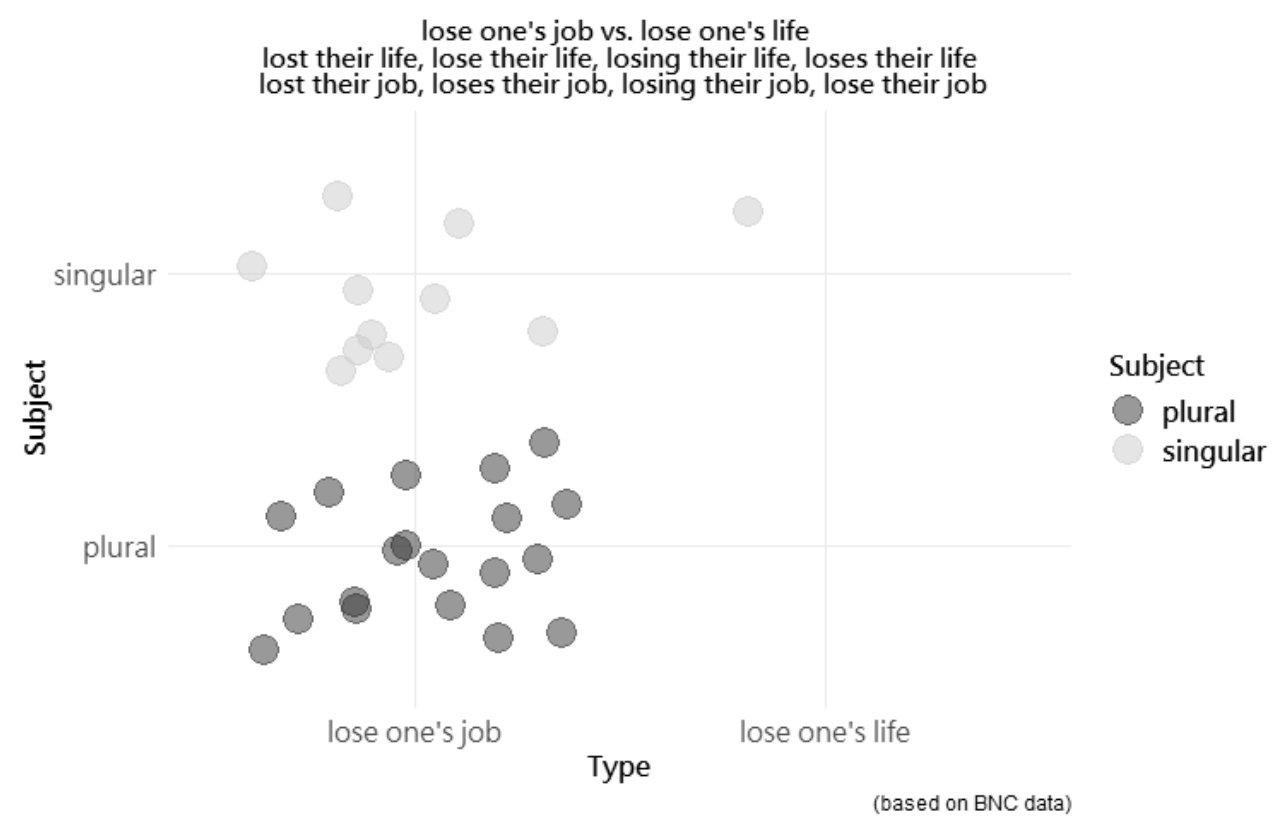

Fig. 6: Cases of singular they for the both types - lose one's life (right) and lose one's job (left); the particular variants are listed in the plot title. Based on BNC data

\section{Discussion}

In the COCA dataset, there are, obviously, more instances of singular they than in the BNC. To provide the clearest explanation, one has to say that COCA itself contains more than one billion words of text, whereas the size of the BNC amounts to 100 million words of text. For the lose one's life type, fifteen times more instances were found in COCA, than in the BNC (all variants counted up); for lose one's job, the difference was $\sim 16.4$ times in favour of COCA.

It is a bit difficult to directly compare both datasets, since COCA is around ten times (to be precise 10.41 times) larger than the BNC, with regard to the number of words (1 $001610938^{11}$ words of text in COCA vs. $96263399^{12}$ words in the BNC). Therefore, to make our datasets comparable in size, we multiply the numbers relevant for the BNC by 10.41 . The question

\footnotetext{
${ }^{11}$ Information retrieved from the webpage at https://www.english-corpora.org/coca/ on July, 30, 2020.

12 Information retrieved from the webpage at https://www.english-corpora.org/bnc/ on July, 30, 2020.
} 
this procedure of extrapolation could answer is "What would the rough numbers be, if the BNC dataset was as big as the COCA dataset". In order to arrive at an answer, we multiply $11^{*} 10.41$ (to get the result for singular they) and $19^{*} 10.41$ (for plural they). The results we arrive at, are 114.5 for the singular they and 197.79 for plural they for the BNC dataset. Table 2 sums up the results. In terms of percentages, this procedure does not change anything, as the proportion of the cases stays the same.

Table 2: Singular and plural they in the BNC and COCA - results after extrapolation

\begin{tabular}{|c|c|c|c|c|}
\hline \multirow{2}{*}{ Variants } & \multicolumn{2}{|c|}{ BNC } & \multicolumn{2}{c|}{ COCA } \\
\cline { 2 - 5 } & singular they & plural they & singular they & plural they \\
\hline $\begin{array}{c}\text { Lose one's life } \\
\text { and lose one's job } \\
\text { - total results }\end{array}$ & $\begin{array}{c}114.51 \text { (after } \\
\text { extrapolation) }\end{array}$ & $\begin{array}{c}197.79 \text { (after } \\
\text { extrapolation) }\end{array}$ & 284 & 308 \\
\hline $\begin{array}{c}\text { Lose one's life } \\
\text { and lose one's job } \\
\text { - total results } \\
\text { in percentages }\end{array}$ & $36.66 \%$ & $63.34 \%$ & $47.97 \%$ & $52.03 \%$ \\
\hline
\end{tabular}

Nevertheless, for both the singular they and plural they, the BNC results after the renormalization are lower that the values obtained for the COCA dataset. Interestingly, the figure for singular they is much lower - 114.5 as compared to 284. This observation might suggest that singular they, at least used with the two constructions in question, seems to be more widely used in the American variety of English. Further support for this claim might be offered by a look at Table 1 and Fig. 5. Strikingly, in the BNC data, there were almost no cases of singular they with the lose one's life construction.

This conclusion goes in line with what Quirk et al. (1985: 770) claim on the topic of singular they, namely "At one time restricted to informal usage, it is now increasingly accepted even in formal usage, especially in $\mathrm{AmE}$ [American English]".

Grammatical changes seem to happen at a rate much slower than it is usual for lexical changes (Mair 2006; McCarthy 2020). Out of the two varieties, the present work looks at, American English is the one which, according to Mair (2006: 188), is "often assumed to lead in the change towards more informal modes of expression in writing". Given this tendency, the fact that the 
singular they seems to be somewhat more frequent in written American English, should not surprise us.

As a counterargument, however, one might raise the fact that COCA contains "younger" material - texts stem from almost three decades between 1990 and 2019, whereas the texts included in the BNC are from the 1980s and early 1990s. In the best-case scenario one could imagine having two corpora containing texts from, for instance, the same decade.

\section{REFERENCES}

Baron, D. (2018). A brief history of singular 'they'. Oxford English Dictionary: The definitive record of the English language. Accessed on July, 20, 2020, available online at https://public.oed.com/blog/a-brief-history-of-singular-they/

Baron, D. (2020). What's your pronoun? Beyond He and She. W. W. Norton.

Bradley, E. D. (2020). The influence of linguistic and social attitudes on grammaticality judgements of singular 'they'. Language Sciences 78.

Gernsbacher, M. A. (1997). Generic pronominal anaphora: The case of the English singular they. Verbum 19 (1-2), 67-8.

Hilpert, M. (2014). Construction Grammar and its application to English. Edinburgh: Edinburgh University Press.

Hoffmann, T.\& Trousdale, G. (2013). Construction Grammar: Introduction. In: The Oxford Handbook of Construction Grammar, T. Hoffmann \& G. Trousdale (eds.).

McCarthy, M. (2020). Innovations and Challenges in Grammar. Routledge: Taylor \& Francis Group.

Mair, Ch. (2006). Twentieth-century English: History, variation and standardization. Cambridge: Cambridge University Press.

Quirk, R., Greenbaum S., Leech G. \& Svartvik J. (1985). A Comprehensive Grammar of the English Language. Edinburgh: Longman.

Solomon, A. N. (2019). The case for singular they and implications for English Language Teaching. TESOL Working Paper Series 17, 69-79.

Weisser, M. (2016). Practical Corpus Linguistics: an Introduction to Corpus-Based Language Analysis. Malden, MA \& Oxford: Wiley-Blackwell.

\section{Language corpora \& Dictionaries}

Davies, M. (2004-) British National Corpus (from Oxford University Press). Available online at https://www.english-corpora.org/bnc/

Davies, M. (2008-) The Corpus of Contemporary American English (COCA): One billion words, 1990-2019. Available online at https://www.english-corpora.org/coca/

Cambridge Online Dictionary, s.v. lose your life, retrieved on May 17, 2020. Available at https://dictionary.cambridge.org/dictionary/english/lose-your-life

Merriam-Webster, s.v. lose one's job, retrieved on May 20, 2020. Available at https://www.merriam-webster.com/dictionary/lose $\% 20$ one $\% 27 \mathrm{~s} \% 20$ job 


\section{Software}

R Core Team (2013). R: A language and environment for statistical computing. R Foundation for Statistical Computing, Vienna, Austria. URL http://www.R-project.org/

RStudio Team. (2020). RStudio: Integrated Development for R. RStudio, PBC, Boston, MA URL http://www.rstudio.com/

Wickham, H. (2016). ggplot2: Elegant Graphics for Data Analysis. Springer-Verlag New York. ISBN 978-3-319-24277-4, URL https://ggplot2.tidyverse.org 